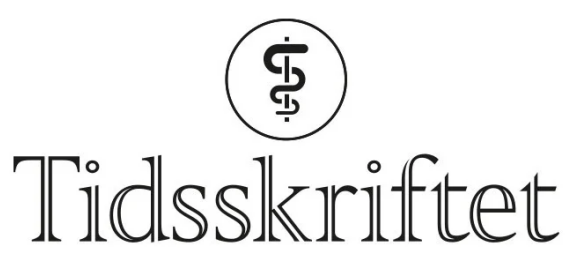

DEN NORSKE LEGEFORENING

\title{
Brev om urett
}

\author{
ANMELDELSER
}

ERIK FOSSE

Avdelingsleder, Intervensjonssenteret, Oslo universitetssykehus

Hans Petter Hougen, Sidsel Rogde

Med døden på arbejde - To retsmedicinere om krig, katastrofer, terror og tortur 376 s, ill. København: Lindhardt og Ringhof, 2021. Pris DKK 300

ISBN 978-87-11-91863-0

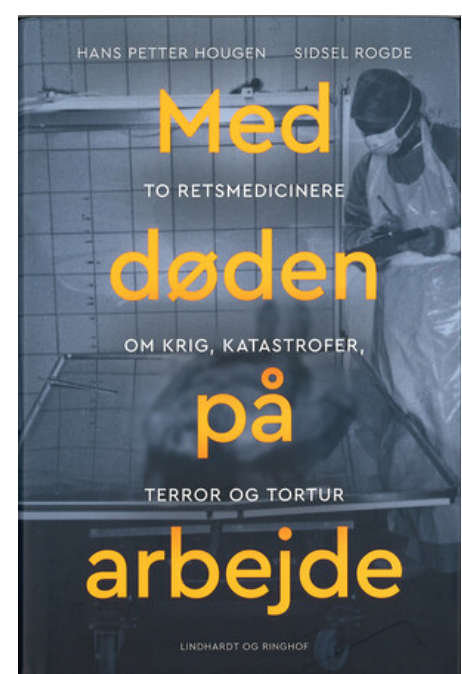

To erfarne rettsmedisinere fra Danmark og Norge deler brevene som de utvekslet fra 1994 til 2018, med oss. Som fortellerteknisk grep fungerer det godt, for forfatterne får da presentert sine erfaringer i en ledig form. Brevformatet gjør det naturlig å ta opp problemstillinger som ikke har med rettsmedisin å gjøre, som når Hougen på vei fra en konferanse på Sri Lanka blir tilbudt barneprostituerte og reflekterer over hvordan fattigdom legitimerer salg av barn. Temaet møter de igjen på flere reiser.

Boken inneholder mange bilder som sammen med menneskerettighetsbetraktningene gjør den interessant for alle samfunnsengasjerte lesere. Begge forfatterne har i tillegg til sitt hjemlige arbeid, deltatt i internasjonale oppdrag for bl.a. Amnesty International og norsk og dansk utenriksdepartement. Vi blir med på disse oppdragene, som består i å identifisere 
ofre og dokumentere hva som kan ha skjedd med dem basert på systematiske undersøkelser - enten det er naturkatastrofer, ulykker, kriminalitet eller tortur. Begge forfatterne har brukt sin rettsmedisinske kompetanse til å avdekke overgrep på sivile over hele verden: fra Filipinene til Mexico, fra Kosovo til Gaza. Fra Gaza kommenterer de også mitt og Mads Gilberts arbeid der.

Siden boken omhandler en periode på 25 år, får vi et innblikk i hvordan den rettsmedisinske verktøykassen har utviklet seg. Etter brannen på Scandinavian Star i 1993 ble DNA-analyser for første gang brukt til identifisering i en masseskadesammenheng. Da et russisk fly tre år senere fløy inn i Operafjellet på Svalbard og 141 personer måtte identifiseres, var DNA-analyse avgjørende.

I brevene diskuterer de ansvaret en rettsmedisiner har i land med dødsstraff. Under en arbeidsperiode i Miami beskrev en av Hougens kolleger volden mot et barn som noe av det verste han hadde sett, noe som førte til at moren, som hadde drept barnet, fikk dødsstraff.

Begge forfatterne deltok i identifiseringen av skandinavene som døde i tsunamien i Thailand i 2009. Intet ble spart for å identifisere de internasjonale turistene og gi dem en verdig begravelse. Samtidig ble tusener av thailendere som mistet livet, brent uten at det ble brukt noen ressurser på å identifisere dem.

Med rettsmedisinsk tyngde dokumenterer Rogde og Hougen forskjellene mellom rike og fattige land og reflekterer rundt hvordan menneskerettigheter blir satt til side.

Publisert: 31. januar 2022. Tidsskr Nor Legeforen. DOI: 10.4045/tidsskr.21.0714

(C) Tidsskrift for Den norske legeforening 2023. Lastet ned fra tidsskriftet.no 26. april 2023. 